\title{
少童養護施設における被䖒待巟の心理的特徵 4
}

\author{
一トラウマ反応と抑うつについて一
}

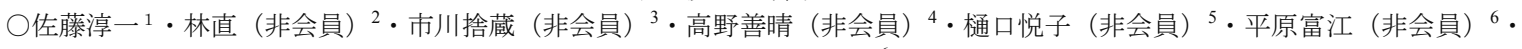
大矢真里 (非会員) ${ }^{6}$

$\left(1\right.$ 上越教育大学・ ${ }^{2}$ 双葉寮・ ${ }^{3}$ 若竹寮・ ${ }^{4}$ 新潟天使園・ 5 若草寮・ ${ }^{6}$ 聖母愛児園 $)$

キーワード: 被虐待児, PTSD, 抑うつ

Post traumatic stress and depression in abused children at protective institution

Junichi SATO ${ }^{1}$, Naoshi HAYASHI ${ }^{2, \#}$, Sutezo ICHIKAWA ${ }^{3, \#}$, Yoshiharu TAKANO ${ }^{4, \#}$, Etsuko HIGUCHI ${ }^{5, \#, ~ T o m i e ~ H I R A H A R A ~}{ }^{6, \#}$ and Mari OOYA $^{6, \#}$

$\left({ }^{1}\right.$ Joetsu University of Education, ${ }^{2}$ protective institution of Futaba, ${ }^{3}$ Wakatake, ${ }^{4}$ Tenshien, ${ }^{5}$ Wakakusa, ${ }^{6}$ Aijien)

Key words: abused child, post traumatic stress, depression

\section{目的}

現在，児童養護施設における被虐待児への心理的援助は臨 床心理士を初めとする心理療法担当員が担っている。心理療 法担当員は心理的援助を要する览童に対して適切な心理査定 と，それに基づいた心理療法を行うことが求められている。 そこで筆者らは，児童養護施設に入所する被虐待経験を持つ 览童の心理的特徵を把握するため, 被虐待児における自己の 全体像の特徵について調査, 報告してきた（山田ら，2010； 山田ら，2011）。それにひきつづき，今回はトラウマ反応と抑 うつについて調査した結果を報告する。

\section{方 法}

調査対象は，A 県内の 5 つの児童養護施設（大舎制）に入 所している中学生の生徒のうち, 入所前に生育歴のなかで被 虐待経験が確認されている小学生 12 名（男子 4 名, 女子 8 名）ならびに中学生 14 名（男子 11 名, 女子 3 名, 平均年齢 13.7 歳) であった。対照群は, A 県内の小学生で, 一般家庭 で生活する小学生高学年 79 名（男子 41 名, 女子 38 名), 中 学生 215 名（男子 110 名, 女子 105 名, 平均年齢 13.3 歳）で あった。なお，各施設の処遇職員や調查参加する児童へは, 事前に同意を得ている。

子どもの心的外傷の程度を測定するため, 子ども版災害後 ストレス反応尺度（富永・高橋・吉田・住本・加治川，2001； Post Traumatic Stress Symptom for Children 15 items: PTSSC15) を用いた。PTSSC15 は, PTSD の代表的な症状からなる PTSD 尺度と抑うつの症状を示寸抑うつ尺度から構成されている。

調査方法は, 質問紙を個別法ならびに集団法により実施し た。質問紙法はフェイスシートとによって構成されている。 実施時間は 10 分から 15 分であった。倫理的配慮として, 調 查への協力は自由であること, 途中で離脱できること, 個人 が特定されることはないことをわかりやすく説明した。調査 協力者の様子について調查後のフォローアップも行っている。

\section{結 果}

PTSSC15 の $\alpha$ 係数は，小学校高学年において PTSD 反応尺 度が 0.89 , 抑うつ尺度が 0.70 , 中学生において PTSD 反応尺 度が 0.86 ，抑うつ尺度が 0.77 であった。

小学生高学年における施設群（被虐待経験有群）と対照群 のPTSS 尺度得点を比較したところ, 施設群は対照群よりも PTSD 得点が有意に高かった $(p<.01)$ 。

中学生における施設群（被虐待経験有群）と対照群の PTSS 尺度得点を比較したところ, 施設群は対照群よりも抑うつ得 点が有意に高かった $(p<.01)$ 。
Table 1

小学生高学年における施設群と対照群の PTSSC15 得点

\begin{tabular}{rrrrrr}
\hline & & $\begin{array}{c}\text { 施設群 } \\
\text { 被虐待経験有 }\end{array}$ & 対照群 & & \\
PTSSC15 & & $(N=12)$ & $(N=79)$ & $t$ 值 & 有意差 \\
\hline PTSD & $M$ & 26.83 & 20.91 & 2.22 & $*$ \\
& $S D$ & 11.36 & 8.14 & & \\
抑うつ & $M$ & 16.50 & 14.51 & 1.21 & \\
& $S D$ & 5.71 & 5.25 & & \\
\hline
\end{tabular}

${ }^{*} p<.05$

Table 2

中学生における施設群と対照群の PTSSC15 得点

\begin{tabular}{rrrrrr}
\hline & & $\begin{array}{r}\text { 施設群 } \\
\text { 被虐待経験有 } \\
(N=14)\end{array}$ & 対照群 & & \\
PTSSC15 & & $N=215)$ & $t$ 值 & 有意差 \\
\hline PTSD & $M$ & 14.00 & 14.11 & 0.94 & \\
& $S D$ & 9.49 & 8.57 & & \\
抑うつ & $M$ & 12.50 & 8.80 & 1.99 & * \\
& $S D$ & 5.47 & 6.11 & & \\
\hline
\end{tabular}

${ }^{*} p<.05$

\section{考 察}

虐待経験のある小学校高学年の児童は, 心的外傷反応を一 般家庭の子どもたちよりも高く示していた。これはこれまで の指摘（前橋, 2001 ; 吉田・武井・山下, 2002） と一致する。 一方, 虐待経験のある中学生の子どもは, 抑うつ反応を一般 家庭の子どもたちよりも高く示していた。これまで易怒性, 侵入性症状, 攻撃的行動の高さ（西澤ら, 1999）や敵意感情 や不安感情の高さ（坪井・森田・松本，2007）が報告されて いることから,抑うつはたんなる気分の落ち込みというより, 被虐待経験に由来すると思われる攻撃性, 敵意, 不安を背景 にしたものの可能性, あるいはその後入所による家族との別 離体験によるものの可能性などが考えられる。いずれにしろ, 心理療法を行うには，こうした側面へのアセスメントや治療 的アプローチが必要になると思われる。

入所児童にとって，過去の被虐待経験とともに，家族と離 れた環境で生活しなければならないという現在の別離体験も ある種の外傷体験となっている可能性も考えられる。今後は, 児童養護施設の入所児童のうち, 被虐待経験を持たない群の データを追加して検討寸る必要がある。 